\title{
Role of IncRNAs in Cellular Aging
}

\author{
Ufuk Degirmenci, ${ }^{1,2}$ and Sun Lei ${ }^{1,3 *}$ \\ 1/nstitute of Molecular and Cell Biology, Agency for Science, Technology and Research, Singapore, ${ }^{2}$ Department of Biological \\ Sciences, National University of Singapore, Singapore, ${ }^{3}$ Programme in Cardiovascular and Metabolic Disorders, Duke-NUS, \\ Singapore
}

Aging is a universal, intrinsic, and time-dependent biological decay that is linked to intricate cellular processes including cellular senescence, telomere shortening, stem cell exhaustion, mitochondrial dysfunction, and deregulated metabolism. Cellular senescence is accepted as one of the core processes of aging at the organism level. Understanding the molecular mechanism underlying senescence could facilitate the development of potential therapeutics for aging and age-related diseases. Recently, the discovery of long non-coding RNAs (IncRNA) provided insights into a novel regulatory layer that can intervene with cellular senescence. Increasing evidence indicates that targeting IncRNAs may impact on senescence pathways. In this review, we will focus on IncRNAs involved in mechanistic pathways governing cellular senescence.

Keywords: senescence, aging, IncRNA, SASP, p21, p53, p16, PRC

\section{INTRODUCTION}

\section{OPEN ACCESS}

Edited by:

Vincenzo De Tata,

University of Pisa, Italy

Reviewed by:

Maria Ines Vaccaro,

University of Buenos Aires, Argentina

Martha Ruskin Stampfer,

University of California, USA

*Correspondence:

Sun Lei

sun.lei@duke-nus.edu.sg

Specialty section:

This article was submitted to Endocrinology of Aging, a section of the journal

Frontiers in Endocrinology

Received: 01 September 2016 Accepted: 22 November 2016 Published: 06 December 2016

Citation:

Degirmenci $U$ and Lei S (2016) Role of IncRNAs in Cellular Aging.

Front. Endocrinol. 7:151. doi: 10.3389/fendo.2016.00151
Aging is a time-dependent decline of physiological capabilities. This progressive decay is caused by multiple factors such as the accumulation of senescent cells, mitochondrial dysfunction, disruption of inter/intracellular signaling, and impairment of metabolic homeostasis. Physiological degeneration is the primary risk factor for the age-related diseases such as Alzheimer, cancer, and type-2 diabetes. World population over 60 is expected to double and reach $22 \%$ by 2050 while countries like Japan, UK, Germany, and Finland will reach that level in next 5 years, and these statistics are calling for further study of aging biology (1).

Cellular senescence can be activated by mitochondrial dysfunction, chromosome destabilization, telomere attrition, DNA damage, and many other stress factors especially those linked to cell cycle. Clearance of senescent cells ( $\mathrm{p} 16^{\mathrm{INK} 4 \mathrm{~A}}$ positive cells) was shown to elongate lifespan in mouse models (2), which supports the idea of the cellular senescence as being one of the contributing factors to the organism aging. Other factors such as immune system clearance defect, shorter telomere size, and accumulation of mutations are also pushing forward the physiological decline during aging. However, a consensus view regarding their relative contributions to aging has yet to merge.

Pathologic effects of senescent cells may impact on overall body due to accumulation of them during aging. The emerging evidence suggests that cellular senescence can affect organisms in at least three different stages. First, senescence impairs tissue regeneration due to exhaustion of stem cells. Second, senescent cells release cytokines and chemokines to interact with other cells, which can result in malfunction at tissue or organism level, a phenotype known as senescence-associated secretory

Abbreviations: CDKN1, cyclin-dependent kinase inhibitor 1; CHK, checkpoint kinase; DDR, DNA damage response; GWAS, genome-wide association study; hnRNP, heterogeneous nuclear ribonucleoproteins; lncRNA, long non-coding RNA; MEF, mouse embryonic fibroblast; ORF, open reading frame; PRC, polycomb repressor complex; SAHF, senescence-associated heterochromatin foci; SASP, senescence-associated secretory phenotype; SCNA, somatic copy number alterations; SMD, staufen1 (STAU1)-mediated mRNA decay; UTR, untranslated region. 
phenotype (SASP) (3-9). SASP can explain how relatively low number of cells can cause problems in organs and overall body performance. Third, cellular senescence could intervene with mitochondrial and cellular metabolism through stress activation that results in disturbed energy homeostasis. In contrasts, cellular senescence seems to have a protective function against tumor formation by limiting cellular replication that is consistent with the interception of senescence pathway with tumor response pathways.

Hayflick and Moorehead challenged the cellular immortality idea with their findings on the limit of cellular replication after extensive passaging $(10,11)$. Later, this senescence type has been linked to telomere attrition, a process that causes chromosomal instability and activates DNA damage response (DDR), which is now known as replicative senescence (4). The DDR pathway is a signal transduction pathway comprised of multiple interacting components. It is initiated by ATM and ATM-Rad3-related (ATR). Downstream of these proteins are checkpoint kinases (CHK1 and CHK2) that phosphorylate and activate downstream effectors such as p53 and p21. Besides telomere attrition, other factors such as UV, oncogenic insult, and chemotherapeutics can also activate DDR and initiate cellular senescence (11-18). In addition, loss of PTEN (tumor suppressor) and overexpression of E2F3 (the S-phase transcription factor) can initiate p53-p21 pathway (19-21).

Senescence activation also occurs through $\mathrm{p} 16^{\mathrm{INK} 4 \mathrm{~A}}$, which represses the CDK4-6-mediated phosphorylation of $\mathrm{pRB}$, thereby blocking cell cycle. This pathway may coordinate with the p53-p21 response, depending on stress signal and/or cell types $(3,22-30)$.

In vitro senescent cells have distinctive characteristics such as increased cell size, accumulation of senescence-associated $\beta$-galactosidase (SA- $\beta$-GAL), activation of survival genes to avoid apoptosis, and the production of the SASP $(7,31-34)$. The discovery of the SASP provided clues to how senescent cells could disrupt the overall homeostasis of the body albeit their relatively low number. The presence of SASP in mammalian cells appeared to be conserved, and some of the proteins in secretome have been repeatedly detected in multiple cell type. Another senescence-linked phenotype is the formation of senescenceassociated heterochromatin foci (SAHFs), which is mainly mediated by $\mathrm{p} 16-\mathrm{pRB}$ pathway. These foci often exist in the genomic loci harboring proliferative genes, thereby inhibiting their expression and activity, but it is important to keep in mind that SHAF does not exist in all senescent cells (35). In senescent cells lacking SAHFs, p16-pRB pathway silences proliferative genes on the epigenetic level as compensatory pathway (36). Currently, measurement of multiple traits mentioned above is the best way to identify senescent cells since each cell type can develop the phenotype with varying order and composition (Figure 1). Figure 1 shows the generic process for cellular senescence while it does not imply the existence of each component in all senescent cells (37-39). Table $\mathbf{1}$ also indicates specific lncRNAs and their targets.

1.

Proliferating State

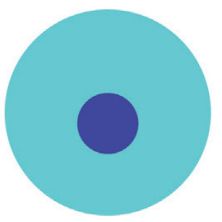

Activating Signals;

Oncogene inactivation

Nucleolar stress

Epigenetic stress

Spindle stress

Tumour suppressor loss

Oncogene activation

Chronic mitogen signalling

Telomere damage

Oxidative stress

DNA damage
Early Senescence

Late Stage Senescence

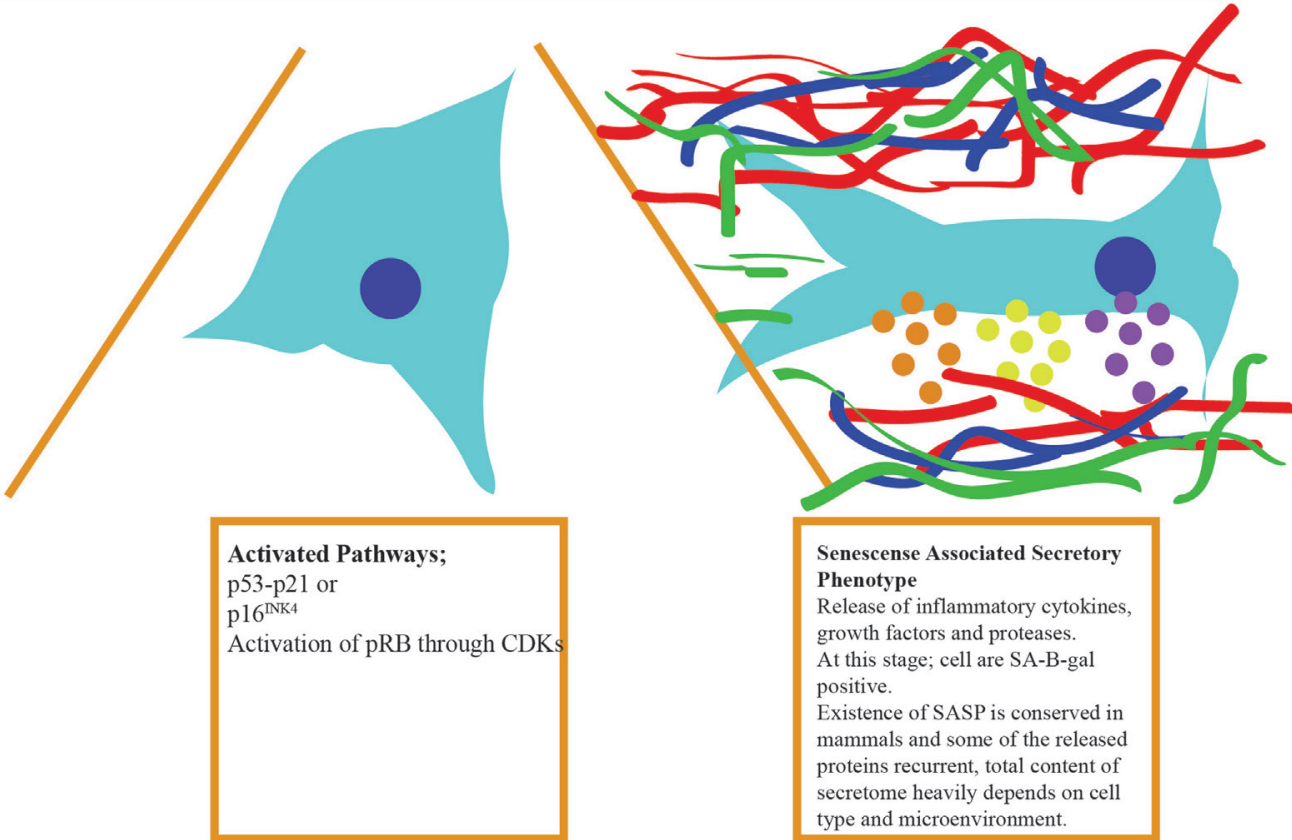

FIGURE 1 | Cellular senescence occurs in three stages: activation of the signaling cascade, the response of the cell by activation of p53-p21/p16 pathways, and late stage when SAHFs are formed and SASP factors are released to cause organ level malfunctions and pathologies. 
TABLE 1 | IncRNAs are here listed with their targets, cell type, and organism in which the experiments performed.

\begin{tabular}{|c|c|c|c|}
\hline LncRNA name & Target & Cell type & $\begin{array}{l}\text { Organism/ } \\
\text { system }\end{array}$ \\
\hline FAL1 & p21 & Cancer cells & Human/in vitro \\
\hline BANCR & p21 & Colorectal cancer cells & Human/in vitro \\
\hline LINCRNA-p21 & $\mathrm{p} 21$ & $\begin{array}{l}\text { Mouse embryonic } \\
\text { fibroblasts }\end{array}$ & $\begin{array}{l}\text { Mouse/in vivo } \\
\text { and in vitro }\end{array}$ \\
\hline MALAT1 & p53 & $\begin{array}{l}\text { Human osteosarcoma } \\
\text { cells }\end{array}$ & Human/in vitro \\
\hline 7SL & p53 & HeLa cells & Human/in vitro \\
\hline VAD & $\begin{array}{l}\text { INK4 locus/ } \\
\text { p16INK4a }\end{array}$ & $\begin{array}{l}\text { hTERT-immortalized } \\
\text { WI38 human fibroblasts }\end{array}$ & Human/in vitro \\
\hline ANRIL & $\begin{array}{l}\text { INK4 locus/ } \\
\text { p16INK4a }\end{array}$ & WI38 cell line & Human/in vitro \\
\hline MIR31HG & $\begin{array}{l}\text { INK4 locus/ } \\
\text { p16INK4a }\end{array}$ & $\begin{array}{l}\text { Immortalized human } \\
\text { diploid fibroblasts, } \\
\text { TIG3-hTERT }\end{array}$ & Human/in vitro \\
\hline UCA1 & $\begin{array}{l}\text { p16INK4a } \\
\text { mRNA }\end{array}$ & Mouse primary cells & Mouse/in vitro \\
\hline SAL-RNA & p53 & $\begin{array}{l}\text { WI38 cell line (old } \\
\text { versus young) }\end{array}$ & Human/in vitro \\
\hline SALNR & $\begin{array}{l}\text { NF-90 } \\
\text { localization }\end{array}$ & Human fibroblast cells & Human/in vitro \\
\hline TERRA & Telomere length & $\begin{array}{l}\text { Mammalian cells and } \\
\text { medulloblastoma }\end{array}$ & \\
\hline ASNCMTRNA2 & hsa-miR-4485 & Human endothelial cells & Human/in vitro \\
\hline HOTAIR & $\begin{array}{l}\text { E3 ubiquitin } \\
\text { ligase and } \\
\text { PRC2 }\end{array}$ & $\begin{array}{l}\text { Ovarian cancer cells } \\
\text { and HeLa cells }\end{array}$ & Human/in vitro \\
\hline PANDA & $\begin{array}{l}\text { PRC1 and } \\
\text { PRC2 } \\
\text { recruitment }\end{array}$ & $\begin{array}{l}\text { Primary human diploid } \\
\text { fibroblast strains, BJ } \\
\text { (neonatal foreskin), and } \\
\text { WI38 (fetal lung) }\end{array}$ & Human/in vitro \\
\hline
\end{tabular}

Same list was also used during generation of Figure 2.

\section{EMERGING REGULATORY LAYER OF DIVERSE BIOLOGICAL PROCESSES}

With protein-coding genes making up to only $2 \%$ of the human genome, the other $98 \%$ have been considered "junk DNA" till the encyclopedia of DNA elements (ENCODE) project and the functional annotation of the mammalian genome (FANTOM) consortium made their early release. They have challenged this concept by identifying a large number of novel transcripts, namely non-coding RNAs (ncRNAs), from the "junk" regions. Based on their transcript lengths, ncRNAs were further divided into small ncRNAs and long ncRNAs (lncRNAs). lncRNAs are a major class of heterogeneous ncRNAs with the lengths more than 200 nucleotides. They are now being recognized as novel regulators in multiple cellular processes, including development, differentiation, chromosome remodeling, imprinting, and cell cycle control (40-44). Research also shows that IncRNAs are tightly regulated and highly tissue specific (43). Moreover, dysregulation of lncRNAs has been associated with human diseases, such as cancer or neurodegenerative disorders (45). However, the functions of most lncRNAs remain uncharacterized $(46,47)$.

Long non-coding RNAs often contain a small open reading frame similar to mRNAs, which was a challenge on their distinction (48). Ribosome-profiling experiments have been employed to address this issue. Initial results of ribosome profiling showed that many lncRNAs were, in fact, ribosome-bound while high sensitivity mass spectrometry failed to identify those small peptides from supposed "IncRNA ORFs" (49). With the help of bioinformatics, ribosome release score has been calculated for protein-coding and non-coding RNAs. Ribosome release score is produced by using ribosome dissociation and association values of given part of RNA. Using this score, most lncRNAs fall into the non-coding category, supporting the results of previous mass spectrometry experiments $(44,50)$.

Regulatory role of lncRNAs in gene expression has been studied. According to these research, their molecular mechanism is quite versatile and there are multiple modes of action $(40,51)$. lncRNAs may regulate gene expression at transcriptional, RNA processing, translational or posttranslational levels by interacting with DNA, RNA, or protein molecules. The subcellular localization of $\operatorname{lncRNAs}$ may also provide additional complexity to their function (52).

Most of the lncRNAs are enriched in the nucleus $(43,53)$, and their localization supports their suggested role in the epigenetic regulation of the chromatin $(54,55)$. They function in cis to regulate the expression of nearby genes or in trans to regulate genes from distant genomic locations. Nuclear lncRNAs often bind to heterogeneous ribonucleoprotein complexes (hnRNPs) and polycomb repressor complex (PRC), consistent with their involvement in modulating epigenetic markers and interacting with transcription factors of target genes. One of the well-known nuclear lncRNAs, Xist, is transcribed from the inactive $\mathrm{X}$ chromosome, and it controls dosage compensation of chromosome $\mathrm{X}$ in human females (56). Xist recruits polycomb repressive complex 2 (PRC2) (56) that switches histone markers to repressive state, and it inhibits transcription of target genes by blocking the access of RNA polymerase II (RNAPII) to inactivated X chromosome (57, 58). PRCs are one of the major binding partners of lncRNAs that has been identified so far. This affinity is explained by intrinsic promiscuity of PRCs and lncRNAs ability to guide PRCs.

Although lncRNAs are generally enriched in the nucleus, many lncRNAs are also detectable in the cytosol. lncRNAs can control mRNA stability by acting as "sponge" for miRNAs in the cytosol. Sponge lncRNAs compete for the miRNA binding site, which results in rescued expression of mRNAs (59). IncRNAs can also associate with a coding gene by overlapping exons to increase the stability of the target mRNA, e.g., BACE1-AS. In contrast, IncRNAs may also be involved in mRNA degradation through Staufen1 (STAU1)-mediated mRNA decay (SMD). This process recognizes double-stranded RNA for degradation. It has been shown that IncRNAs can form RNA-RNA duplex with $3^{\prime}$-UTRs of target mRNA at Alu elements and cause SMD (60). lncRNA-mRNA complex (bound by Alu element) can be the result of imperfect base pairing, and this double-stranded RNA 
complex activates SMD, which happens through recruitment of UPF1 (regulator of nonsense transcript-1) that shortens the poly-A tail. Shortened poly-A translates to the shorter lifespan for mRNA (61). Another function is that H19 is transported to the cytosol, where it is used as a source of microRNA (miR-675) to suppress growth (62-71).

In this review, we will focus on the recent studies about lncRNAs involved in cellular senescence $(66,72-77)$. To incorporate lncRNAs into the known regulatory network, we discussed lncRNAs according to their interactions with known key proteins such as p53/p21, p16, CDKs, and pRb (3-5, 12, 15, 23-25, 27, 28, 30, 78, 79) (Figure 2).

\section{IncRNAs ARE INVOLVED IN p21 PATHWAY REGULATION (CDKN1A-p21)}

Several lncRNAs, as discussed below, have been reported to modulate expression of p21 in different ways. Although the involvement of these p21-regulating lncRNAs in aging has not been directly demonstrated, given the key role of p21 in cellular senescence, it warrants further investigation on how these lncRNAs may participate in cellular senescence regulation through $\mathrm{p} 21$.

\section{Focally Amplified IncRNA on Chromosome 1}

$\mathrm{Hu}$ et al. focused on somatic copy number alterations (SCNAs) of lncRNAs. By analyzing a genome-wide survey on SCNAs of lncRNA in 2394 tumor specimens from 12 types of cancer, they identified a correlation between copy number of focally amplified lncRNA on chromosome 1 (FAL1) and progression of ovarian cancer. They found out that FAL1 interacts and stabilizes the epigenetic repressor BMI1 (the PRC1 core protein) so as to repress p 21 expression. Silencing FAL1 with siRNAs significantly blocked tumor growth in vivo. The interaction between FAL1 and BMI1 highlights how lncRNAs can take a central role in epigenetic regulation of p21 $(80,81)$.

\section{BRAF-Activated Non-Coding RNA}

BRAF-activated non-coding RNA (BANCR) is a lncRNA required for cell migration in different types of cancer (82-84). Shi et al. investigated its contribution to colorectal cancer. They showed that BANCR expression was significantly decreased in colorectal cancer, and when BANCR is overexpressed, it slowed down the growth of colorectal cancer. They also suggested that pcDNA-BANCR-mediated proliferation was linked to activation of G0/G1 cell cycle arrest through regulation of p21. Effects of BANCR were probably post-transcriptional since protein expression levels of $\mathrm{p} 21$ increased while that of mRNA remained unchanged. In brief, this article suggests that downregulation of BANCR contributes to the translational regulation of $\mathrm{p} 21$ protein (85).

\section{LincRNA-P21}

LincRNA-p21 plays a role in regulating p21 levels. Upon DNA damage, p53 activates lincRNA-p21 that is located next to the p21 gene. In the nucleus, lincRNA-p21 activates transcription of $\mathrm{p} 21$ by recruiting hnRNP-K to the promoter region of $\mathrm{p} 21$ (86). Using conditional lincRNA-p21 knockout mouse model, Dimitrova et al. showed that loss of lincRNA-p21 could block p21 expression and it can activate mouse embryonic fibroblasts (MEFs) expansion. In the cytoplasm, lincRNA-p21 bound HuR recruits the let-7/Ago2 complex to destabilize lincRNA-p21. LincRNA-p21 also associates with its target mRNAs by base pairing and suppresses their translation with the Rck RNA helicase $(86,87)$.

\section{IncRNAs INVOLVED IN p53 REGULATION}

\section{Metastasis-Associated Lung Adenocarcinoma Transcript 1}

The transcript of metastasis-associated lung adenocarcinoma transcript 1 (MALAT1) gene was first identified in 1997 (88), and it is highly expressed in several type of cancers (89). In 2010, MALAT1 was reported as a highly abundant nuclear transcript localized to the nuclear speckles (a region which is enriched in pre-mRNA splicing factors) $(90,91)$. In 2013, Tripathi et al. performed genome-wide transcriptome analyses in human fibroblasts. Their result indicated that MALAT1 controlled the expression of cell cycle genes and was required for cell cycle progression (92). They also showed that depletion of MALAT1 leads to activation of the p53 pathway and p53 is required for MALAT1 dependent cell cycle arrest. Moreover, MALAT1-depleted cells have low levels of B-MYB (Mybl2, an oncogenic transcription factor), leading to the discovery of aberrant alternative splicing of B-MYB pre-mRNA. However, the exact mechanism of how MALAT1 impacts p53 signaling needs further investigation $(91,92)$.

\section{SL}

In 1991, Sakamoto et al. cloned 7SL sequence partially (93). They observed the 7SL would block proliferation of HeLa cells. Recently, Abdelmohsen et al. showed that 7SL forms a partial hybrid with the $3^{\prime}$-untranslated region (UTR) of p53 mRNA. The association of 7SL with p53 mRNA reduced p53 translation. When 7SL were silenced, it increased the interaction between HuR and TP53 mRNA, stabilizing TP53 mRNA and increasing p53 translation. The antagonist activity between 7SL and HuR for TP53 3' UTR contributes to the fine tuning of p53 translation (94).

\section{IncRNAs REGULATING CDKN2A}

Very long intergenic non-coding RNA-vlincRNA antisense to DDAH1 (VAD) and ANRIL have been identified from senescent cells and found to have an impact on cellular senescence while MIR31HG and UCA1 have been identified through oncogenic pathways.

\section{Very Long Intergenic Non-Coding RNA-vlincRNA Antisense to DDAH1}

Lazorthes et al. have analyzed the differentially expressed strandspecific transcription during oncogene-induced senescence 


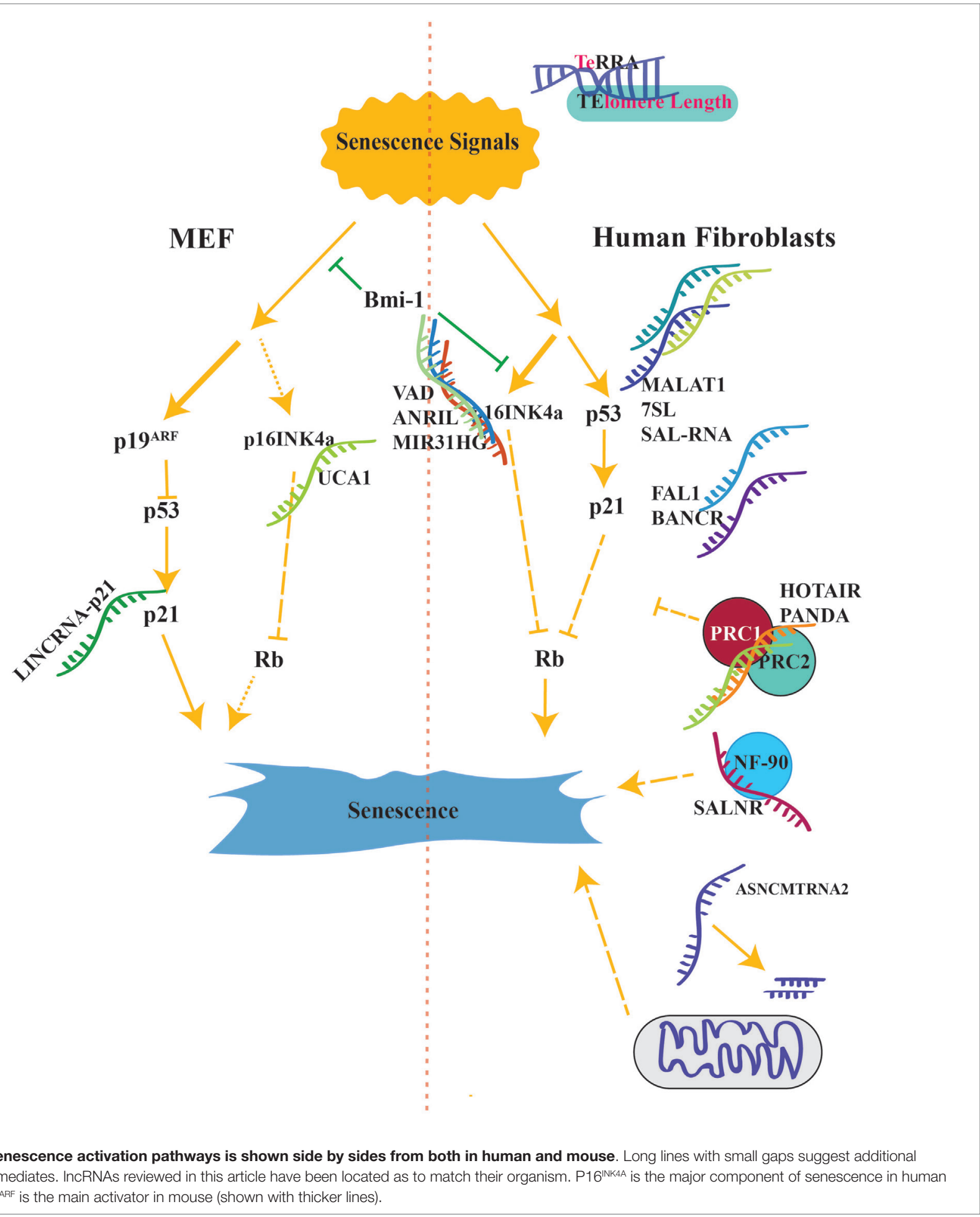

FIGURE 2 | Senescence activation pathways is shown side by sides from both in human and mouse. Long lines with small gaps suggest additional unknown intermediates. IncRNAs reviewed in this article have been located as to match their organism. P16 ${ }^{\text {INK } 4 \mathrm{~A}}$ is the major component of senescence in human cells while p19ARF is the main activator in mouse (shown with thicker lines).

in human. They identified that most vlincRNAs $(>50 \mathrm{~kb})$ are induced during senescence. They showed that VAD, one of the antisense vlincRNAs, was highly expressed during senescence and it is essential for maintaining senescence phenotype. VAD regulates chromatin structure in cis and activates gene expression in trans at the INK4 locus. Moreover, VAD blocks the recruitment of H2A.Z, repressive histone variant, into the proximity of INK4 gene in senescent cells and maintains transcription of it (95). 


\section{Antisense Non-Coding RNA in the INK4 Locus, CDKN2B-AS}

Antisense non-coding RNA in the INK4 locus is produced from 9 p21 on human chromosome locus where p16 ${ }^{\text {INK4A }}$ and $\mathrm{p} 15^{\mathrm{INK} 4 \mathrm{~B}}$ (p15 in mouse) are transcribed. SNPs in ANRIL gene are linked to various diseases in genome-wide association studies (GWAS). Additionally, silencing of this locus affects cellular proliferation, and it has been found that polycomb complex is recruited to this region by ANRIL via SUZ12 (a component of polycomb complex). Silencing of ANRIL produces senescent cells that are stained positive for beta-galactosidase. Current research suggests that ANRIL recruits PRC1 and PRC2 to INK4 region to initiate and maintain silenced chromatin signature: H3K27ME and H2AK119ub1 (96, 97). Therefore, ANRIL maintains the proliferative state by blocking senescence genes.

\section{MIR31 Host Gene}

MIR31 host gene is located $400 \mathrm{~kb}$ upstream of the p16 $6^{\mathrm{INK} 4 \mathrm{~A}}$ locus on chromosome 9 in human. Previously, decreased expression of MIR31HG has been shown to reduce cell growth and activate strong senescence phenotype (98). Recently, Montes et al. found that the lncRNA MIR31HG was highly expressed in senescence and silencing of MIR31HG activates p16 $6^{\text {INK4A }}$ expression (99). In pre-senescent cells, MIR31HG is located in both nucleus and cytoplasm, but after B-RAF (proto-oncogene) transcription, MIR31HG is specifically present in the cytoplasm. Their results showed that MIR31HG could bind to both $\mathrm{p} 16^{\mathrm{INK} 4 \mathrm{~A}}$ and MIR31HG genomic regions. Additionally, polycomb group $(\mathrm{PcG})$ proteins and MIR31HG are necessary for PcG-mediated repression of the $\mathrm{p} 16^{\mathrm{INK} 4 \mathrm{~A}}$ locus. Hence, their data suggested a new lncRNA-mediated inhibition of the p16 ${ }^{\mathrm{INK} 4 \mathrm{~A}}(99)$.

\section{Urothelial Cancer-Associated 1}

Kumar et al. discovered that CAPER $\alpha / \mathrm{TBX} 3$ repressor complex was required to prevent senescence in primary cells and mouse embryos. CAPER $\alpha / \mathrm{TBX} 3$ complex regulates chromatin structure and represses transcription of CDKN2A-p16. Inhibiting CAPER $\alpha /$ TBX3 induced the IncRNA UCA1 expression, in which UCA1 overexpression induced senescence. In proliferating cells, hnRNPA1 can bind and destabilize p16 ${ }^{\mathrm{INK} 4 \mathrm{~A}}$ mRNA. However, during senescence, UCA1 expression stabilizes p $16^{\text {INK4A }}$ mRNAs by disrupting the association of hnRNP A1 with p16 ${ }^{\mathrm{INK} 4 \mathrm{~A}}$ mRNA $(100,101)$.

\section{ACTIVATION OF SENESCENCE THROUGH OTHER PATHWAYS}

\section{Senescence-Associated IncRNAs}

Abdelmohsen et al. identified differentially expressed novel lncRNAs between young versus old human diploid WI-38 fibroblasts populations. These populations are 32 days apart from each other in doubling time. Among those novel lncRNAs, they selected three lncRNAs to further study their involvement in cellular senescence and proliferation. Decreasing expression of those lncRNAs resulted in increased p53 expression, thereby affecting cell survival and senescence (102). However, exact mechanism requires further study.

\section{Senescence-Associated Long Non-Coding RNA}

Using human fibroblast cells, Wu et al. performed genome-wide screening of lncRNA expression in cellular senescence. They have identified lncRNAs with differential expressions in senescent cells in contrast with young cells. Within these lncRNAs, they further selected a specific senescence-associated lncRNA (SALNR) that has low expression in senescent cells. When they overexpressed the SALNR, cellular senescence was delayed.

Furthermore, they found that SALNR physically interacts with NF90 (nuclear factor of activated T-cells, $90 \mathrm{kDa}$ ), which is able to suppress biogenesis of senescence-associated miRNAs, such as miR-22 and miR-181a. Inhibiting NF90 resulted in premature senescence since NF90 is the suppressor of senescence miRNAs.

Moreover, when cells were exposed to Ras-induced stress (activates senescence), NF90 gets translocated to nucleolus and NF90 can no longer suppress senescence-associated miRNA biogenesis, which can be rescued by SALNR overexpression. Thus, SALNR antagonizes NF90 translocation into nucleolus and rescues its inhibitory activity on senescenceassociated miRNA expression. Their data suggest that lncRNA SALNR controls cellular senescence through modulating NF90 localization (103).

\section{Telomeric Repeat-Containing RNA}

First, telomeric repeat-containing RNA has been identified in yeast and it has a specific hotspot in the subject of senescence. It forms DNA-RNA pairing with telomere region at R-loop formation that contains G-quadruplex, TERRA, and TERRAbinding proteins. TERRA also increases upon DNA damage at telomere region to involve in recombination and DNA repair. Arnoult et al. showed that TERRA expression decreases upon telomere elongation in multiple cancer cell lines (104). Elongated telomeres have less TERRA expression due to tightly packed telomeric repeats with $\mathrm{HP} 1 \alpha$ and $\mathrm{H} 3 \mathrm{~K} 9 \mathrm{me} 3$, which make chromosome inaccessible to the transcription machinery.

In parallel, increased levels of TERRA was also found in several primary human tumors containing short telomeres (105). In other words, TERRA is reversely correlated with telomere length.

On a different research, TERRA was shown to maintain the telomere length in the lack of telomerase enzyme as explained above. RNA-DNA complex formed between TERRA and telomeres postpones the senescence by activating homologous recombination at telomeres (106). These suggest multiple functions for TERRA on telomere length and maintenance; however, further research is required to unravel the detailed mechanism of how TERRA functions in telomere and telomerase during aging (107-109). 


\section{MITOCHONDRIAL IncRNA INVOLVED IN SENESCENCE}

\section{ASNCMTRNA2 (mtDNA-Transcribed Long-Non-Coding-RNA-2)}

Villegas et al. have first reported a mitochondrial transcript of 2374 nucleotides whose expression correlates with the cellular replication (110). Following up this project, Burzio et al. have reported the existence of two antisense mitochondrial transcripts that were expressed in proliferating cells from healthy human tissues but decreased in tumor samples (111). Recently, Bianchessi et al. showed that two miRNAs, hsa-miR-4485 and hsa-miR-1973, have perfect homology with ASncmtRNA-2. Both miRNAs are upregulated in endothelial cells at replicative senescence. ASncmtRNA-2 overexpression results in an increased expression of hsa-miR-4485. It induces cell cycle arrest at G2/M phase. Moreover, the overexpression of the two miRNAs shows the similar phenotype, cell cycle delay in both the G1 and G2/M phases. They proposed that ASncmtRNA-2 is involved in replicative senescence in endothelial cells by causing cell cycle arrest in the transition from G2/M to G1 (112).

\section{MAINTENANCE OF SENESCENCE}

\section{HOX Transcript Antisense RNA}

The human lncRNA HOX transcript antisense RNA (HOTAIR) is transcribed from the HOXC locus of homeobox genes as an approximately 2.2-kb RNA (113). It binds to the enhancer of zeste homolog 2 (EZH2) in the polycomb repressive complex 2 (PRC2) and to lysine-specific demethylase 1 (LSD1), which are chromatin remodeling factors $(113,114)$. Both complexes lead to gene silencing and are recruited in trans to hundreds of genomic sites by HOTAIR. Recently, Ozes et al demonstrated a novel function of HOTAIR in DDR, which is regulating the expression of genes to block proliferation. Their results showed that after induction of DNA damage, HOTAIR activates the cellular senescence through NF- $\mathrm{BB}$ pathway. Furthermore, they demonstrated the presence of a positive-feedback loop that induces HOTAIR. This activates DDR and sustains NF- $\kappa \mathrm{B}$ expression (115). Recently, Yoon et al. reported a function of IncRNA HOTAIR as a scaffold for ubiquitin-mediated proteolysis in posttranslational control (116). First, HOTAIR binds to E3 ubiquitin ligases through RNA-binding domains, Dzip3 and Mex3b, and to their ubiquitination targets: Ataxin-1 and Snurportin-1, respectively. As a result, HOTAIR assists the ubiquitination of Ataxin-1 by Dzip3 and Snurportin-1 by Mex $3 b$ and speeds up their degradation. HOTAIR expression is increased in senescent cells, resulting in the degradation of Ataxin-1 and Snurportin-1 (116). Their results suggested a novel scaffold function for a lncRNA that can impact on senescence.

\section{P21-Associated ncRNA DNA Damage Activated}

With the help of super high-resolution tiling array analysis in CDKN1 region, Puvvula et al. identified P21-associated ncRNA
DNA damage activated (PANDA) as a lncRNA, which is induced upon DNA damage.

P21-associated ncRNA DNA damage activated plays a dual role in proliferating cells versus senescent cells. In proliferating cells, scaffold-attachment-factor A/hnRNPU (SAFA) interacts with lncRNA PANDA to block senescence genes by recruiting PRC1 and PRC2 to senescence activating genes loci including CDKN1. Silencing SAFA and PANDA induces cell cycle arrest, and it also causes senescence in proliferating cells by allowing transcription of senescence activating genes.

In senescent cells, SAFA-PANDA-PRC interactions are blocked therefore, pro-senescence genes are transcribed. PANDA inhibits the expression of proliferative genes by sequestering the transcription factor NF-YA from occupying its target promoters in senescent cells. Depletion of PANDA in the senescent cells reactivates proliferative genes and allows cells to replicate (117).

\section{CONCLUSION AND PERSPECTIVES}

As concluding remarks, with the recent advancement in technology, our understanding on the function of lncRNAs has expanded vastly. Here, we have summarized an emerging role of lncRNAs as regulators of cellular senescence and age-related diseases. Albeit of these progresses, lncRNAs in senescence field is still in its infancy so as lncRNAs in general. Most of these studies remain at the cellular level, but the evidence that lncRNAs can regulate aging process in vivo has yet to be established.

Understanding lncRNAs function may help us fill some knowledge gap in genetic causes for human phenotypes. Many SNPs are not associated with coding genes but with non-coding region where lncRNAs may be transcribed (118). For example, a recent study on Asian centurions revealed a novel SNP rs2440012 associated with longevity (119). Given the growing evidence of the functional role lncRNAs in physiological and pathological processes, we believe it is just a matter of time to illustrate role of lncRNAs in aging.

\section{AUTHOR CONTRIBUTIONS}

UD wrote the manuscript. SL reviewed and edited the manuscript.

\section{ACKNOWLEDGMENTS}

This is a short text to acknowledge the contributions of specific colleagues, institutions, or agencies that aided the efforts of the authors.

\section{FUNDING}

This work was supported by Singapore NRF fellowship (NRF2011NRF-NRFF 001-025) to SL. This research is also supported by the Singapore National Research Foundation under its CBRG grant (NMRC/CBRG/0070/2014 and NMRC/CBRG/0101/2016) and administrated by the Singapore Ministry of Health's National Medical Research Council. This work is also supported by A*STAR SINGA scholarship to UD. 


\section{REFERENCES}

1. Armanios M. Telomeres and age-related disease: how telomere biology informs clinical paradigms. JClin Invest (2013) 123(3):996-1002. doi:10.1172/JCI66370

2. Baker DJ, Childs BG, Durik M, Wijers ME, Sieben CJ, Zhong J, et al. Naturally occurring p16 $6^{\text {Ink4a }}$-positive cells shorten healthy lifespan. Nature (2016) 530(7589):184-9. doi:10.1038/nature16932

3. López-Otín C, Blasco MA, Partridge L, Serrano M, Kroemer G. The hallmarks of aging. Cell (2013) 153(6):1194-217. doi:10.1016/j.cell.2013. 05.039

4. van Deursen JM. The role of senescent cells in ageing. Nature (2014) 509(7501):439-46. doi:10.1038/nature13193

5. Munoz-Espin D, Serrano M. Cellular senescence: from physiology to pathology. Nat Rev Mol Cell Biol (2014) 15(7):482-96. doi:10.1038/nrm3823

6. Kuilman T, Michaloglou C, Mooi WJ, Peeper DS. The essence of senescence. Genes Dev (2010) 24(22):2463-79. doi:10.1101/gad.1971610

7. Dimri GP, Lee X, Basile G, Acosta M, Scott G, Roskelley C, et al. A biomarker that identifies senescent human cells in culture and in aging skin in vivo. Proc Natl Acad Sci U S A (1995) 92:9363-7.

8. Geng YQ, Guan JT, Xu XH, Fu YC. Senescence-associated beta-galactosidase activity expression in aging hippocampal neurons. Biochem Biophys Res Commun (2010) 396(4):866-9. doi:10.1016/j.bbrc.2010.05.011

9. Coppé JP, Patil CK, Rodier F, Sun Y, Muñoz DP, Goldstein J, et al. Senescence-associated secretory phenotypes reveal cell-nonautonomous functions of oncogenic RAS and the p53 tumor suppressor. PLoS Biol (2008) 6(12):2853-68. doi:10.1371/journal.pbio.0060301

10. Hayflick L. The limited in vitro lifetime of human diploid cell strains. Exp Cell Res (1965) 37:614-36. doi:10.1016/0014-4827(65)90211-9

11. Hayflick L, Moorhead PS. The serial cultivation of human diploid cell strains. Exp Cell Res (1961) 25:585-621. doi:10.1016/0014-4827(61)90192-6

12. Ungewitter E, Scrable H. Antagonistic pleiotropy and p53. Mech Ageing Dev (2009) 130(1-2):10-7. doi:10.1016/j.mad.2008.06.002

13. Chen Z, Carracedo A, Lin HK, Koutcher JA, Behrendt N, Egia A, et al. Differential p53-independent outcomes of p19Arf loss in oncogenesis. Science (2009) 2(84):ra44. doi:10.1126/scisignal.2000053

14. Xue W, Zender L, Miething C, Dickins RA, Hernando E, Krizhanovsky V, et al. Senescence and tumour clearance is triggered by p53 restoration in murine liver carcinomas. Nature (2007) 445(7128):656-60. doi:10.1038/ nature05529

15. Webley K, Bond JA, Jones CJ, Blaydes JP, Craig A, Hupp T, et al. Posttranslational modifications of p53 in replicative senescence overlapping but distinct from those induced by DNA damage. Mol Cell Biol (2000) 20:2803-8. doi:10.1128/MCB.20.8.2803-2808.2000

16. Ben-Porath I, Weinberg RA. The signals and pathways activating cellular senescence. Int J Biochem Cell Biol (2005) 37(5):961-76. doi:10.1016/j. biocel.2004.10.013

17. Lim CS. Cellular senescence, cancer, and organismal aging: a paradigm shift. Biochem Biophys Res Commun (2006) 344(1):1-2. doi:10.1016/j. bbrc.2006.03.161

18. Lin HK, Chen Z, Wang G, Nardella C, Lee SW, Chan CH, et al. Skp2 targeting suppresses tumorigenesis by Arf-p53-independent cellular senescence. Nature (2010) 464(7287):374-9. doi:10.1038/nature08815

19. Freund A, Patil CK, Campisi J.p38MAPK is a novel DNA damage response-independent regulator of the senescence-associated secretory phenotype. EMBO J (2011) 30(8):1536-48. doi:10.1038/emboj.2011.69

20. d'Adda di Fagagna F, Reaper PM, Clay-Farrace L, Fiegler H, Carr P, Von Zglinicki T, et al. A DNA damage checkpoint response in telomere-initiated senescence. Nature (2003) 426(6963):194-8. doi:10.1038/nature02118

21. Zhou B-BS, Elledge SJ. The DNA damage response: putting checkpoints in perspective. Nature (2000) 408(6811):433-9. doi:10.1038/35044005

22. Beauséjour CM, Krtolica A, Galimi F, Narita M, Lowe SW, Yaswen P, et al. Reversal of human cellular senescence: roles of p53 and p16 pathways. EMBO $J$ (2003) 22:4212-22. doi:10.1093/emboj/cdg417

23. Baker DJ, Wijshake T, Tchkonia T, LeBrasseur NK, Childs BG, van de Sluis B, et al. Clearance of $16^{\text {Ink4a }}$-positive senescent cells delays ageing-associated disorders. Nature (2011) 479(7372):232-6. doi:10.1038/ nature 10600
24. Krishnamurthy J, Ramsey MR, Ligon KL, Torrice C, Koh A, Bonner-Weir S, et al. p16 ${ }^{\text {INK4a }}$ induces an age-dependent decline in islet regenerative potential. Nature (2006) 443(7110):453-7. doi:10.1038/nature05092

25. Krishnamurthy J, Torrice C, Ramsey MR, Kovalev GI, Al-Regaiey K, Su L, et al. Ink4a/Arf expression is a biomarker of aging. J Clin Invest (2004) 114(9):1299-307. doi:10.1172/JCI22475

26. Sharpless NE, Bardeesy N, Lee KH, Carrasco D, Castrillon DH, Aguirre AJ, et al. Loss of $\mathrm{p} 16^{\text {Ink4a }}$ with retention of $\mathrm{p} 19$ Arf predisposes mice to tumorigenesis. Nature (2001) 413(6851):86-91. doi:10.1038/35092592

27. Alcorta DA, Xiong Y, Phelps D, Hannon G, Beach D, Barrett JC. Involvement of the cyclin-dependent kinase inhibitor p16 (INK4a) in replicative senescence of normal human fibroblasts. PNAS (1996) 93(24):13742-7. doi:10.1073/pnas.93.24.13742

28. Baker DJ, Perez-Terzic C, Jin F, Pitel KS, Niederländer NJ, Jeganathan K, et al. Opposing roles for $16^{\text {Ink4a }}$ and p19Arf in senescence and ageing caused by BubR1 insufficiency. Nat Cell Biol (2008) 10(7):825-36. doi:10.1038/ncb1744

29. Wu CH, van Riggelen J, Yetil A, Fan AC, Bachireddy P, Felsher DW. Cellular senescence is an important mechanism of tumor regression upon c-Myc inactivation. Proc Natl Acad Sci U S A (2007) 104(32):13028-33. doi:10.1073/ pnas.0701953104

30. Serrano M, Lin AW, McCurrach ME, Beach D, Lowe SW. Oncogenic ras provokes premature cell senescence associated with accumulation of p53 and p16 ${ }^{\text {INK4a }}$. Cell (1997) 88:593-602.

31. Hampel B, Wagner M, Teis D, Zwerschke W, Huber LA, Jansen-Dürr P. Apoptosis resistance of senescent human fibroblasts is correlated with the absence of nuclear IGFBP-3. Aging Cell (2005) 4(6):325-30. doi:10.1111/j.1474-9726.2005.00180.x

32. Ryu SJ, Oh YS, Park SC. Failure of stress-induced downregulation of Bcl-2 contributes to apoptosis resistance in senescent human diploid fibroblasts. Cell Death Differ (2007) 14(5):1020-8. doi:10.1038/sj.cdd.4402091

33. Wenqi Chen JK, Kang J, Xia J, Li Y, Yang B, Chen B, et al. p53-related apoptosis resistance and tumor suppression activity in UVB-induced premature senescent human skin fibroblasts. Int J Mol Med (2008) 21:645-53. doi:10.3892/ijmm.21.5.645

34. Pasillas MP, Shields S, Reilly R, Strnadel J, Behl C, Park R, et al. Proteomic analysis reveals a role for $\mathrm{Bcl} 2$-associated athanogene 3 and major vault protein in resistance to apoptosis in senescent cells by regulating ERK1/2 activation. Mol Cell Proteomics (2015) 14(1):1-14. doi:10.1074/mcp.M114. 037697

35. Narita M, Nũnez S, Heard E, Narita M, Lin AW, Hearn SA, et al. Rb-mediated heterochromatin formation and silencing of E2F target genes during cellular senescence. Cell (2003) 113(6):703-16. doi:10.1016/S0092-8674(03) 00401-X

36. Macaluso M, Montanari M, Giordano A. Rb family proteins as modulators of gene expression and new aspects regarding the interaction with chromatin remodeling enzymes. Oncogene (2006) 25(38):5263-7. doi:10.1038/ sj.onc. 1209680

37. Childs BG, Durik M, Baker DJ, van Deursen JM. Cellular senescence in aging and age-related disease: from mechanisms to therapy. Nat Med (2015) 21(12):1424-35. doi:10.1038/nm.4000

38. Acosta JC, Banito A, Wuestefeld T, Georgilis A, Janich P, Morton JP, et al. A complex secretory program orchestrated by the inflammasome controls paracrine senescence. Nat Cell Biol (2013) 15(8):978-90. doi:10.1038/ ncb2784

39. Salminen A, Kauppinen A, Kaarniranta K. Emerging role of NF-kappaB signaling in the induction of senescence-associated secretory phenotype (SASP). Cell Signal (2012) 24(4):835-45. doi:10.1016/j.cellsig.2011.12.006

40. Rinn JL, Chang HY. Genome regulation by long noncoding RNAs. Ann Rev Biochem (2012) 81:145-66. doi:10.1146/annurev-biochem-051410092902

41. Solé C, Nadal-Ribelles M, de Nadal E, Posas F. A novel role for lncRNAs in cell cycle control during stress adaptation. Curr Genet (2015) 61(3):299-308. doi:10.1007/s00294-014-0453-y

42. Harrow J, Frankish A, Gonzalez JM, Tapanari E, Diekhans M, Kokocinski F, et al. GENCODE: the reference human genome annotation for The ENCODE Project. Genome Res (2012) 22(9):1760-74. doi:10.1101/gr.135350.111

43. Derrien T, Johnson R, Bussotti G, Tanzer A, Djebali S, Tilgner H, et al. The GENCODE v7 catalog of human long noncoding RNAs: analysis of their 
gene structure, evolution, and expression. Genome Res (2012) 22(9):1775-89. doi:10.1101/gr.132159.111

44. Guttman M, Russell P, Ingolia NT, Weissman JS, Lander ES. Ribosome profiling provides evidence that large non-coding RNAs do not encode proteins. Cell (2013) 154(1):240-51. doi:10.1016/j.cell.2013.06.009

45. Taft RJ, Pang KC, Mercer TR, Dinger M, Mattick JS. Non-coding RNAs: regulators of disease. J Pathol (2010) 220(2):126-39. doi:10.1002/path.2638

46. Lu Q, Ren S, Lu M, Zhang Y, Zhu D, Zhang X, et al. Computational prediction of associations between long non-coding RNAs and proteins. BMC Genomics (2013) 14:651. doi:10.1186/1471-2164-14-651

47. Li J, Xuan Z, Liu C. Long non-coding RNAs and complex human diseases. Int J Mol Sci (2013) 14(9):18790-808. doi:10.3390/ijms140918790

48. Andrews SJ, Rothnagel JA. Emerging evidence for functional peptides encoded by short open reading frames. Nat Rev Genet (2014) 15(3):193-204. doi:10.1038/nrg3520

49. Gascoigne DK, Cheetham SW, Cattenoz PB, Clark MB, Amaral PP, Taft RJ, et al. Pinstripe: a suite of programs for integrating transcriptomic and proteomic datasets identifies novel proteins and improves differentiation of protein-coding and non-coding genes. Bioinformatics (2012) 28(23):3042-50. doi:10.1093/bioinformatics/bts582

50. Ingolia NT, Lareau LF, Weissman JS. Ribosome profiling of mouse embryonic stem cells reveals the complexity of mammalian proteomes. Cell (2011) 147(4):789-802. doi:10.1016/j.cell.2011.10.002

51. Ulitsky I, Bartel DP. lincRNAs: genomics, evolution, and mechanisms. Cell (2013) 154(1):26-46. doi:10.1016/j.cell.2013.06.020

52. Elling R, Chan J, Fitzgerald KA. Emerging role of long noncoding RNAs as regulators of innate immune cell development and inflammatory gene expression. Eur J Immunol (2016) 46(3):504-12. doi:10.1002/eji. 201444558

53. Djebali S, Davis CA, Merkel A, Dobin A, Lassmann T, Mortazavi A, et al. Landscape of transcription in human cells. Nature (2012) 489(7414):101-8. doi:10.1038/nature11233

54. Khalil AM, Guttman M, Huarte M, Garber M, Raj A, Rivea Morales D, et al. Many human large intergenic noncoding RNAs associate with chromatin-modifying complexes and affect gene expression. Proc Natl Acad Sci U S A (2009) 106(28):11667-72. doi:10.1073/pnas.0904715106

55. MondalT, Rasmussen M, Pandey GK, Isaksson A, Kanduri C. Characterization of the RNA content of chromatin. Genome Res (2010) 20(7):899-907. doi:10.1101/gr.103473.109

56. McHugh CA, Chen CK, Chow A, Surka CF, Tran C, McDonel P, et al. The Xist lncRNA directly interacts with SHARP to silence transcription through HDAC3. Nature (2015) 521(7551):232-6. doi:10.1038/nature14443

57. Wilusz JE, Sunwoo H, Spector DL. Long noncoding RNAs: functional surprises from the RNA world. Genes Dev (2009) 23(13):1494-504. doi:10.1101/ gad.1800909

58. Chaumeil J, Le Baccon P, Wutz A, Heard E. A novel role for Xist RNA in the formation of a repressive nuclear compartment into which genes are recruited when silenced. Genes Dev (2006) 20(16):2223-37. doi:10.1101/ gad.380906

59. Hu G, Tang Q, Sharma S, Yu F, Escobar TM, Muljo SA, et al. Expression and regulation of lincRNAs during $\mathrm{T}$ cell development and differentiation. Nat Immunol (2013) 14(11):1190-8. doi:10.1038/ni.2712

60. Casero D, Sandoval S, Seet CS, Scholes J, Zhu Y, Ha VL, et al. LncRNA profiling of human lymphoid progenitors reveals transcriptional divergence of B and T lineages. Nat Immunol (2015) 16(12):1282-91. doi:10.1038/ ni.3299

61. Jiang K, Sun X, Chen Y, Shen Y, Jarvis JN. RNA sequencing from human neutrophils reveals distinct transcriptional differences associated with chronic inflammatory states. BMC Med Genomics (2015) 8:55. doi:10.1186/ s12920-015-0128-7

62. Werner MS, Ruthenburg AJ. Nuclear fractionation reveals thousands of chromatin-tethered noncoding RNAs adjacent to active genes. Cell Rep (2015) 12(7):1089-98. doi:10.1016/j.celrep.2015.07.033

63. Ounzain S, Pedrazzini T. Super-enhancer lncs to cardiovascular development and disease. Biochim Biophys Acta (2016) 1863(7 Pt B):1953-60. doi:10.1016/j. bbamcr.2015.11.026

64. Lai F, Gardini A, Zhang A, Shiekhattar R. Integrator mediates the biogenesis of enhancer RNAs. Nature (2015) 525(7569):399-403. doi:10.1038/ nature14906
65. Pott S, Lieb JD. What are super-enhancers? Nat Genet (2015) 47(1):8-12. doi:10.1038/ng.3167

66. Quinn JJ, Chang HY. RNA switch at enhancers. Nat Genet (2014) 46(9):92931. doi:10.1038/ng.3074

67. Bonasio R, Shiekhattar R. Regulation of transcription by long noncoding RNAs. Annu Rev Genet (2014) 48:433-55. doi:10.1146/ annurev-genet-120213-092323

68. Orom UA, Shiekhattar R. Long noncoding RNAs usher in a new era in the biology of enhancers. Cell (2013) 154(6):1190-3. doi:10.1016/j. cell.2013.08.028

69. Hnisz D, Abraham BJ, Lee TI, Lau A, Saint-André V, Sigova AA, et al. Transcriptional super-enhancers connected to cell identity and disease. Cell (2013) 155(4):53. doi:10.1016/j.cell.2013.09.053

70. Li H, Gade P, Nallar SC, Raha A, Roy SK, Karra S, et al. The Med1 subunit of transcriptional mediator plays a central role in regulating CCAAT/ enhancer-binding protein-beta-driven transcription in response to interferon-gamma. J Biol Chem (2008) 283(19):13077-86. doi:10.1074/jbc. M800604200

71. Blackwood EM, Kadonaga JT. Going the distance: a current view of enhancer action. Science (1998) 281(5373):60-3. doi:10.1126/science.281. 5373.60

72. Fatica A, Bozzoni I. Long non-coding RNAs: new players in cell differentiation and development. Nat Rev Genet (2014) 15(1):7-21. doi:10.1038/nrg3606

73. Schaukowitch K, Kim TK. Emerging epigenetic mechanisms of long non-coding RNAs. Neuroscience (2014) 264:25-38. doi:10.1016/j. neuroscience.2013.12.009

74. Clark BS, Blackshaw S. Long non-coding RNA-dependent transcriptional regulation in neuronal development and disease. Front Genet (2014) 5:164. doi:10.3389/fgene.2014.00164

75. Lee JT. Epigenetic regulation by long noncoding RNAs. Science (2012) 338:1435-9. doi:10.1126/science. 1231776

76. Pefanis E, Wang J, Rothschild G, Lim J, Kazadi D, Sun J, et al. RNA exosome-regulated long non-coding RNA transcription controls super-enhancer activity. Cell (2015) 161(4):774-89. doi:10.1016/j.cell.2015.04.034

77. Bergmann JH, Spector DL. Long non-coding RNAs: modulators of nuclear structure and function. Curr Opin Cell Biol (2014) 26:10-8. doi:10.1016/j. ceb.2013.08.005

78. Niederer RO, Papadopoulos N, Zappulla DC. Identification of novel noncoding transcripts in telomerase-negative yeast using RNA-seq. Sci Rep (2016) 6:19376. doi:10.1038/srep19376

79. Kozlowski M, Ladurner AG. ATM, MacroH2A.1, and SASP: the checks and balances of cellular senescence. Mol Cell (2015) 59(5):713-5. doi:10.1016/j. molcel.2015.08.010

80. Hu X, Feng Y, Zhang D, Zhao SD, Hu Z, Greshock J, et al. A functional genomic approach identifies FAL1 as an oncogenic long noncoding RNA that associates with BMI1 and represses p21 expression in cancer. Cancer Cell (2014) 26(3):344-57. doi:10.1016/j.ccr.2014.07.009

81. Zhong X, Hu X, Zhang L. Oncogenic long noncoding RNA FAL1 in human cancer. Mol Cell Oncol (2015) 2(2):e977154. doi:10.4161/23723556.2014.97 7154

82. Zhang ZX, Liu ZQ, Jiang B, Lu XY, Ning XF, Yuan CT, et al. BRAF activated non-coding RNA (BANCR) promoting gastric cancer cells proliferation via regulation of NF-KB1. Biochem Biophys Res Commun (2015) 465(2):225-31. doi:10.1016/j.bbrc.2015.07.158

83. Sun M, Liu XH, Wang KM, Nie FQ, Kong R, Yang JS, et al. Downregulation of BRAF activated non-coding RNA is associated with poor prognosis for non-small cell lung cancer and promotes metastasis by affecting epithelialmesenchymal transition. Mol Cancer (2014) 13:68-68. doi:10.1186/ 1476-4598-13-68

84. Flockhart RJ, Webster DE, Qu K, Mascarenhas N, Kovalski J, Kretz M, et al. $\mathrm{BRAF}(\mathrm{V} 600 \mathrm{E})$ remodels the melanocyte transcriptome and induces BANCR to regulate melanoma cell migration. Genome Res (2012) 22(6):1006-14. doi:10.1101/gr.140061.112

85. Shi Y, Liu Y, Wang J, Jie D, Yun T, Li W, et al. Downregulated long noncoding RNA BANCR promotes the proliferation of colorectal cancer cells via downregualtion of p21 expression. PLoS One (2015) 10(4):e0122679. doi:10.1371/ journal.pone.0122679

86. Dimitrova N, Zamudio JR, Jong RM, Soukup D, Resnick R, Sarma K, et al. LincRNA-p21 activates p21 In cis to promote polycomb target gene 
expression and to enforce the G1/S checkpoint. Mol Cell (2014) 54(5):777-90. doi:10.1016/j.molcel.2014.04.025

87. Yoon JH, Abdelmohsen K, Srikantan S, Yang X, Martindale JL, De S, et al. LincRNA-p21 suppresses target mRNA translation. Mol Cell (2012) 47(4):648-55. doi:10.1016/j.molcel.2012.06.027

88. Marx SJ. Molecular genetics of multiple endocrine neoplasia types 1 and 2. Nat Rev Cancer (2005) 5(5):367-75. doi:10.1038/nrc1610

89. Hutchinson JN, Ensminger AW, Clemson CM, Lynch CR, Lawrence JB, Chess A. A screen for nuclear transcripts identifies two linked noncoding RNAs associated with SC35 splicing domains. BMC Genomics (2007) 8(1):39. doi:10.1186/1471-2164-8-39

90. Spector DL, Lamond AI. Nuclear speckles. Cold Spring Harb Perspect Biol (2011) 3(2):a000646. doi:10.1101/cshperspect.a000646

91. Tripathi V, Ellis JD, Shen Z, Song DY, Pan Q, Watt AT, et al. The nuclear-retained noncoding RNA MALAT1 regulates alternative splicing by modulating SR splicing factor phosphorylation. Mol Cell (2010) 39(6):925-38. doi:10.1016/j.molcel.2010.08.011

92. Tripathi V, Shen Z, Chakraborty A, Giri S, Freier SM, Wu X, et al. Long noncoding RNA MALAT1 controls cell cycle progression by regulating the expression of oncogenic transcription factor B-MYB. PLoS Genet (2013) 9(3):e1003368. doi:10.1371/journal.pgen.1003368

93. Sakamoto K, Fordis CM, Corsico CD, Howard TH, Howard BH. Modulation of HeLa cell growth by transfected 7SL RNA and Alu gene sequences. J Biol Chem (1991) 266(5):3031-8.

94. Abdelmohsen K, Panda AC, Kang MJ, Guo R, Kim J, Grammatikakis I, et al. 7SL RNA represses $\mathrm{p} 53$ translation by competing with HuR. Nucleic Acids Res (2014) 42(15):10099-111. doi:10.1093/nar/gku686

95. Lazorthes S, Vallot C, Briois S, Aguirrebengoa M, Thuret JY, St Laurent $\mathrm{G}$, et al. A vlincRNA participates in senescence maintenance by relieving H2AZ-mediated repression at the INK4 locus. Nat Commun (2015) 6:5971. doi:10.1038/ncomms6971

96. Kotake Y, Nakagawa T, Kitagawa K, Suzuki S, Liu N, Kitagawa M, et al. Long non-coding RNA ANRIL is required for the PRC2 recruitment to and silencing of p15(INK4B) tumor suppressor gene. Oncogene (2011) 30(16):1956-62. doi:10.1038/onc.2010.568

97. Yap KL, Li S, Muñoz-Cabello AM, Raguz S, Zeng L, Mujtaba S, et al. Molecular interplay of the noncoding RNA ANRIL and methylated histone H3 lysine 27 by polycomb CBX7 in transcriptional silencing of INK4a. Mol Cell (2010) 38(5):662-74. doi:10.1016/j.molcel.2010.03.021

98. Shi Y, Lu J, Zhou J, Tan X, He Y, Ding J, et al. Long non-coding RNA Loc554202 regulates proliferation and migration in breast cancer cells. Biochem Biophys Res Commun (2014) 446(2):448-53. doi:10.1016/j.bbrc.2014.02.144

99. Montes M, Nielsen MM, Maglieri G, Jacobsen A, Højfeldt J, Agrawal-Singh S, et al. The lncRNA MIR31HG regulates p16(INK4A) expression to modulate senescence. Nat Commun (2015) 6:6967. doi:10.1038/ncomms7967

100. Kumar PP, Emechebe U, Smith R, Franklin S, Moore B, Yandell M, et al. Coordinated control of senescence by $\operatorname{lncRNA}$ and a novel T-box3 co-repressor complex. Elife (2014) 3:e02805. doi:10.7554/eLife. 02805

101. Xue M, Chen W, Li X. Urothelial cancer associated 1: a long noncoding RNA with a crucial role in cancer. J Cancer Res Clin Oncol (2016) 142(7):1407-19. doi:10.1007/s00432-015-2042-y

102. Abdelmohsen K, Panda A, Kang MJ, Xu J, Selimyan R, Yoon JH, et al. Senescence-associated lncRNAs: senescence-associated long noncoding RNAs. Aging Cell (2013) 12(5):890-900. doi:10.1111/acel.12115

103. Wu CL, Wang Y, Jin B, Chen H, Xie BS, Mao ZB. Senescence-associated Long Non-coding RNA (SALNR) Delays Oncogene-induced Senescence through NF90 Regulation. J Biol Chem (2015) 290(50):30175-92. doi:10.1074/jbc. M115.661785

104. Arnoult N, Van Beneden A, Decottignies A. Telomere length regulates TERRA levels through increased trimethylation of telomeric H3K9

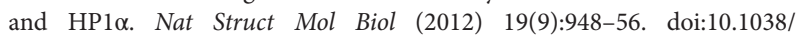
nsmb.2364
105. Deng Z, Wang Z, Xiang C, Molczan A, Baubet V, Conejo-Garcia J, et al. Formation of telomeric repeat-containing RNA (TERRA) foci in highly proliferating mouse cerebellar neuronal progenitors and medulloblastoma. J Cell Sci (2012) 125(18):4383-94. doi:10.1242/jcs.108118

106. Balk B, Maicher A, Dees M, Klermund J, Luke-Glaser S, Bender K, et al. Telomeric RNA-DNA hybrids affect telomere-length dynamics and senescence. Nat Struct Mol Biol (2013) 20(10):1199-205. doi:10.1038/nsmb.2662

107. Azzalin CM, Reichenbach P, Khoriauli L, Giulotto E, Lingner J. Telomeric repeat-containing RNA and RNA surveillance factors at mammalian chromosome ends. Science (2007) 318(5851):798-801. doi:10.1126/science. 1147182

108. Porro A, Feuerhahn S, Lingner J. TERRA-reinforced association of LSD1 with MRE11 promotes processing of uncapped telomeres. Cell Rep (2014) 6(4):765-76. doi:10.1016/j.celrep.2014.01.022

109. Lustig AJ. Telomerase RNA: a flexible RNA scaffold for telomerase biosynthesis. Curr Biol (2004) 14(14):R565-7. doi:10.1016/j.cub.2004.07.013

110. Villegas J, Burzio V, Villota C, Landerer E, Martinez R, Santander M, et al. Expression of a novel non-coding mitochondrial RNA in human proliferating cells. Nucleic Acids Res (2007) 35(21):7336-47. doi:10.1093/nar/gkm863

111. Burzio VA, Villota C, Villegas J, Landerer E, Boccardo E, Villa LL, et al. Expression of a family of noncoding mitochondrial RNAs distinguishes normal from cancer cells. Proc Natl Acad Sci U S A (2009) 106(23):9430-4. doi:10.1073/pnas.0903086106

112. Bianchessi V, Badi I, Bertolotti M, Nigro P, D’Alessandra Y, Capogrossi MC, et al. The mitochondrial IncRNA ASncmtRNA-2 is induced in aging and replicative senescence in Endothelial Cells. J Mol Cell Cardiol (2015) 81:62-70. doi:10.1016/j.yjmcc.2015.01.012

113. Rinn JL, Kertesz M, Wang JK, Squazzo SL, Xu X, Brugmann SA, et al. Functional demarcation of active and silent chromatin domains in human HOX loci by noncoding RNAs. Cell (2007) 129(7):1311-23. doi:10.1016/j. cell.2007.05.022

114. Tsai MC, Manor O, Wan Y, Mosammaparast N, Wang JK, Lan F, et al. Long noncoding RNA as modular scaffold of histone modification complexes. Science (2010) 329(5992):689-93. doi:10.1126/science.1192002

115. Ozes AR, Miller DF, Özeş ON, Fang F, Liu Y, Matei D, et al. NF-kappaBHOTAIR axis links DNA damage response, chemoresistance and cellular senescence in ovarian cancer. Oncogene (2016) 35(41):5350-61. doi:10.1038/ onc. 2016.75

116. Yoon J-H, Abdelmohsen K, Kim J, Yang X, Martindale JL, TominagaYamanaka $\mathrm{K}$, et al. Scaffold function of long non-coding RNA HOTAIR in protein ubiquitination. Nat Commun (2013) 4:2939. doi:10.1038/ ncomms 3939

117. Puvvula PK, Desetty RD, Pineau P, Marchio A, Moon A, Dejean A, et al. Long noncoding RNA PANDA and scaffold-attachment-factor SAFA control senescence entry and exit. Nat Commun (2014) 5:5323. doi:10.1038/ ncomms6323

118. Iyer MK, Niknafs YS, Malik R, Singhal U, Sahu A, Hosono Y, et al. The landscape of long noncoding RNAs in the human transcriptome. Nat Genet (2015) 47(3):199-208. doi:10.1038/ng.3192

119. Zeng Y, Nie C, Min J, Liu X, Li M, Chen H, et al. Novel loci and pathways significantly associated with longevity. Sci Rep (2016) 6:21243. doi:10.1038/ srep21243

Conflict of Interest Statement: The authors declare that the research was conducted in the absence of any commercial or financial relationships that could be construed as a potential conflict of interest.

Copyright $\odot 2016$ Degirmenci and Lei. This is an open-access article distributed under the terms of the Creative Commons Attribution License (CC BY). The use, distribution or reproduction in other forums is permitted, provided the original author(s) or licensor are credited and that the original publication in this journal is cited, in accordance with accepted academic practice. No use, distribution or reproduction is permitted which does not comply with these terms. 